\title{
OUR KNOWLEDGE OF GOD: THE RELEVANCE OF THE DEBATE BETWEEN EUNOMIUS AND THE CAPPADOCIANS ${ }^{1}$
}

\author{
Graham A. Keith
}

The Arian Controversy, spanning at least seventy years, did not run along a single track. ${ }^{2}$ We would expect the issues to shift over such a period of time, especially if recent scholarship is right in recognising in Arius himself a rather isolated figure both theologically and ecclesiastically. ${ }^{3}$

The issues posed by Arius were, however, real concerns of the day even if few followed Arius exactly. The Council of Nicaea may have pointed the way to some answers; but its significance was lost for almost a generation until the emergence of a movement of extreme Arian tendency. It was dubbed Anomoeanism by its opponents because of its bland affirmation that the Son of God was unlike (dvofuocos) the Father in substance. Recent scholarship, however, has preferred to use the term Neo-Arianism to designate this movement. ${ }^{4}$

This title does leave open whether the movement was reproducing the teaching of Arius in a new guise or not. I believe that in its beginnings the movement reflected a brazen

\footnotetext{
${ }^{1}$ In this paper I have concentrated on those works of Basil of Caesarea and Gregory of Nyssa which seek directly to refute the writings of Eunomius. These make up one extended controversy. For details see R.P. Vaggione Eunomius: The Extant Works (OUP 1987) XV. This means that I have not treated the work of Gregory of Nazianzus, whose justly famous Theological Orations, delivered in Constantinople in 380, are directed primarily against Eunomius' partisans in the city, but envisage popular Neo-Arian theologising rather than a specific document.

It is generally agreed that the Arian Controversy began about 318. The death of Eunomius sometime in the 390's marks a rough terminal point. Though Arian and Neo-Arian groups persisted after this point, they ceased to be in the forefront of doctrinal debate. In effect, they became sectarian churches.

${ }^{3}$ See R. Williams Arius-Heresy and Tradition (London, Darton Longman and Todd 1987) p.233f. and R.P.C. Hanson, The Search for the Christian Doctrine of God (Edinburgh, T. \& T. Clark 1988) 123-8.

${ }^{4}$ The term was canonized in English by T.A. Kopecek in his two-volume work $A$ History of Neo-Arianism (Cambridge, Mass., Philadelphia Patristic Foundation, 1979). It is accepted in R.P.C. Hanson's magisterial study op. cit. cf. ch. 19.
} 
restatement of Arius' position sharpened on the anvil of debate and moulded by the tools of logic, though in time new emphases were to emerge.

Neo-Arianism stressed the question of theological language. In one sense this had been implicit in the opening shots of the Arian Controversy. Arius had objected to his bishop's statement 'Always the Father, always the Son'5 and had produced his counter-slogan "There was when the Son of God was not'. ${ }^{6}$ But the implications of this for the status of the Son and for God's paternity were not extensively explored in the early stages of the controversy.

The Neo-Arians reacted against the primacy accorded to the names Father and Son, despite their traditional standing in the church. They preferred a different tradition to which they gave an elevated status and a new significance. They put forward the term $d \gamma \epsilon \nu \nu \eta T o s$ (unbegotten) as the most appropriate designation of the Supreme Being. ${ }^{7}$ Indeed, they even made God 'unbegotten essence'. Or, to use a form of expression beloved of the Neo-Arians themselves, 'unbegotten' was the name of God par excellence. ${ }^{8}$ In time they boldly claimed that God could be known in his very essence. At the same time they categorically denied that unbegottenness could be correctly

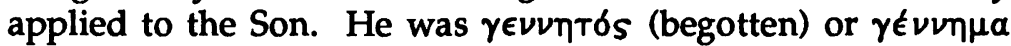
(offspring). Aetius, the founder-figure of Neo-Arianism, could even say that the Christian hope depended on maintaining a more than purely verbal distinction between the unbegotten and the begotten. 9

It is important to consider the extent of this Neo-Arian innovation. The term d $\gamma \hat{\epsilon} \nu \nu \eta \bar{r}$ s had played a significant role

\footnotetext{
${ }^{5}$ H.G. Opitz Athanasius Werke, III 1 Urkunden zur Geschichte des Arianischen Streites (Berlin and Leipzig, Walter de Gruyter, 1935) Nos 1:2 and 6:1.

${ }^{6}$ Ibid. Nos 4b:7 and 14:10.

${ }^{7}$ The word $d \gamma \in v \nu \eta T o s$ has occasioned English translators considerable difficulty, for reasons which will appear below. Renderings include 'unbegotten' (Vaggione, Williams), 'ingenerate' (Wickham, Hanson, Prestige), 'ungenerated' (Kopecek) and 'unengendered' (Kelly). Since I quote below from Vaggione's translation of Eunomius, I have for consistency employed his translation.

${ }^{8}$ E.g. Aetius, Syntagmation 12. This work is edited and translated by L.R. Wickham in Journal of Theological Studies N.S. XIX (1968) 532-69.

${ }^{9}$ Ibid. 16.
} 
in the early stages of the Arian Controversy. Arius had used it $^{10}$ but equally the word had been a favourite with Arius' opponent, Bishop Alexander of Alexandria. ${ }^{11}$ In fact, the word had a long history antedating the Arian Controversy-a history complicated by the persistent failure among writers to distinguish between $\dot{\alpha} \gamma \epsilon \nu \nu \eta T O S$ (unbegotten from $\gamma \in \nu \nu d \omega=I$ beget) and $\dot{\alpha} \gamma \epsilon \nu \eta$ Tos (uncreated from $\gamma\left(\gamma \nu\right.$ oual $=\mathrm{I}$ become). ${ }^{12}$ 'A $\boldsymbol{y}^{\epsilon} \nu[\nu] \eta$ Tos, deriving immediately from a Middle-Platonist milieu, entered the Christian tradition through the second-century apologists, Justin Martyr and Athenagoras. ${ }^{13}$ These had resolutely affirmed one unoriginated supreme being. Moreover, their concept of unoriginatedness was far from being a negative one, despite the linguistic form of the word. The word had connotations of perfection. Irenaeus, for example, in contrasting man with God has this to say: 'Since creatures subsequently acquired an independent beginning of temporal existence, on that very ground they are bound to be inferior to Him who made them. Objects recently created cannot be agenetos. Inasmuch as they are not agenetos they are inferior to what is perfect ${ }^{1}{ }^{14}$ Irenaeus goes on to argue that God in his generosity has brought the glory of the unoriginated within man's reach, if he makes due progress. Irenaeus concludes: Man gently progresses and rises towards perfection, that is to say, he approximates to the ageneton. For the perfect One is the agenetos One, that is God'.

But who was this unoriginated being? Kopecek concluded that in the second and third centuries Christian practice reserved the term for God the Father in a massive number of cases, with only three clear examples where the Son was also described as á $\gamma^{\epsilon} \nu \nu \eta T o s .{ }^{15}$ No doubt, most Christians demurred at using this of the Son because it had become standard practice to talk of him as 'begotten'. Yet the ambiguity surrounding a $\gamma \epsilon \nu \nu \eta T$ Tos and $a \gamma \epsilon \nu \eta T$ Tos left some questions open. Could the

\footnotetext{
${ }^{10}$ E.g. Opitz Urkunden 1.

${ }^{11}$ E.g. Opitz Urkunden 14:44 and 52.

${ }^{12}$ Cf. the comments of G.L. Prestige in God in Patristic Thought (London, SPCK;

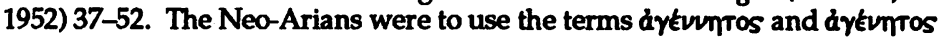
interchangeably - see Vaggione op. cit. 29.

${ }^{13}$ Kopecek op. cit. $242 \mathrm{ff}$.

${ }^{14}$ Irenaeus haer. 4:38:1f. The translation is that of Prestige in op. cit. 44-5.

${ }^{15}$ Kopecek op. cit. $244-66$
} 
Son in any sense be described as $₫ \gamma \epsilon \nu \nu \eta$ Tos? To do so might obliterate the distinction between the Father and the Son. On the other hand, if the Son was categorically denied to be ¿ $\gamma \in \nu \nu \eta T o s$, wherein did he differ from the created order?

The Neo-Arians, in their emphasis on unbegottenness and in their insistence that this term applied only to the Supreme Being, could claim some support from previous Christian tradition. But so far was Christian tradition from

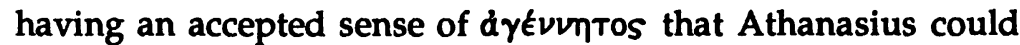
object that the term was ambivalent. ${ }^{16}$ But in the mid-fourth century no one would drop the word simply because of some imprecision. Given its honoured place in Christian tradition, the onus lay with the doubters to downgrade or discredit the term. Ironically, the greatest damage it suffered came from the exaggerated claims of the Neo-Arians. The most successful opposition did not try to discredit it, but to downplay it.

\section{Emphasising dyEvuntos}

To Aetius 'unbegotten' was the incomparable name-giving true expression to God's dignity. ${ }^{17}$ But in early Arianism the term had no such far-reaching significance. Athanasius does record that for popular Arian exponents Is the unbegotten one or two?' was part of a battery of questions designed to heighten the difference between the Father and the Son. ${ }^{18}$ But there is no hint that unbegottenness was the lynch-pin of their theology. With Arius' extreme view on divine incomprehensibility ${ }^{19}$ - that the Father was not even known to the Son except to a limited extent-there could be no talk of knowing the divine essence . The use of the term dirtuvntos by some of Arius' leading opponents is further evidence that the word had yet to become a distinctive feature of the Arian armoury.

Some change occurred as a result of the activities of one of Arius' most indefatigable supporters, Asterius the Sophist, who used his position as a layman to spread Arian doctrines without the same threat of discipline as would have attended

\footnotetext{
${ }^{16}$ Oratio contra Arianos 1:30; De Decretis 28-32.

${ }^{17}$ Syntagmation 12.

${ }^{18}$ Oratio contra Arianos 1:30.

${ }^{19}$ Williams op. cit. $210 \mathrm{ff}$.
} 
a regular member of the clergy. He wrote a compendium of theology containing a definition of dykvuntos-The unbegotten is that which has not been created, but always is' ${ }^{20}$ As Athanasius pointed out, if that were the correct definition, then the Son as well as the Father could be properly termed a $\gamma \epsilon \nu \nu \eta T$ s. And then there would at least be two beings to be

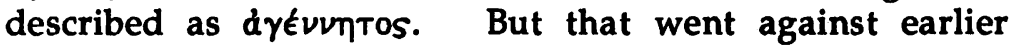
Christian tradition.

Herein Aetius followed Asterius' definition. His understanding of unbegottenness also involved being above any form of causation or origination. ${ }^{21}$ Moreover, the unbegotten God must abide in the same condition continually. ${ }^{22}$ But in his further assertion that unbegottenness denoted the essence of God, Aetius was developing a line of his own. Curious as it may seem, Aetius was most influenced by his bête noire, Athanasius. Kopecek has convincingly argued that Aetius was particularly scandalized by Athanasius' defence of the Creed of Nicaea in his work De Decretis published around $350 .{ }^{23}$ He took up his own position in deliberate opposition, but as often happens in bitter doctrinal disputes, there was common ground between the two protagonists.

Section 22 of Athanasius' work is particularly significant. Here Athanasius defends the Nicene fathers in their assertion that the Son was from the ovola of the Father-an assertion beyond the letter of scripture. Athanasius contends that this was a legitimate step because the only alternative to saying the Son was from God's ovola would be to say he proceeded from something around ( $\pi \epsilon p l)$ God. ${ }^{24}$ But to assert the latter would either infringe God's simplicity or else would make the Son just another of the creatures-in which case the title 'Son' was a misnomer. Aetius shared Athanasius' view of the divine simplicity. There was no place for talking of things around God. A title genuinely denoting God must refer to his essence. Both Athanasius and Aetius were influenced by an exegesis of Exodus 3:14, 'I am that I $\mathrm{am}^{\prime}$ ( $\left.\delta \Phi v\right)$, as the

${ }^{20}$ Quoted by Athanasius at Oratio contra Arianos 1:30.

${ }^{21}$ Cf. Syntagmation 2.

${ }^{22}$ Ibid. 4.

${ }^{23}$ Kopecek op. cit. $120 \mathrm{ff}$.

${ }^{24}$ De Decretis 22:1-2. 
revelation of the divine name. ${ }^{25}$ But while Athanasius would assign all scriptural titles like 'Father', 'God' and 'Lord' to the divine essence, Aetius' approach was quite different. ${ }^{26}$ 'Father' simply denoted the 'power' or 'activity' of God, ${ }^{27}$ whereas 'unbegotten' denoted the divine essence. In brief, Aetius and Athanasius shared the same basic position on the divine simplicity; they disagreed on its relationship to the various titles given to God.

Athanasius had unwittingly set an agenda for NeoArianism. He flung down a further gauntlet by his treatment of a $\gamma \epsilon=\nu \eta T o s$, when he affirmed that God was so called from his works. ${ }^{28}$ For, he argued, in one of its main senses d $\gamma \notin \nu \nu \eta T o s$ was a term of contrast with things which have an origin. It was a word like 'Maker' which derives from God's relationship to the created order. Athanasius still did not care for the word, preferring the term 'Father' because that automatically implied the Son. Aetius, however, reversed this. The term

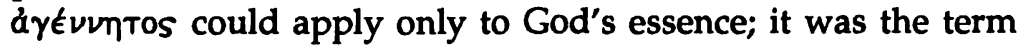
Father' which derived from his works.

\section{The position of Eunomius}

\section{(a) Background}

The best insight into the ethos of developed Neo-Arianism is found in the literary war between Eunomius, initially Aetius' pupil but later the great systematiser of the movement, and Basil of Caesarea. With their debate after 360 the Arian Controversy entered upon a new phase. Eunomius had emerged as the most formidable intellectual exponent of Arianism. This arose from his considerable dialectical and literary skills. Partly for political reasons and partly through a disinclination towards the practicalities of church-planting, Eunomius may

\footnotetext{
${ }^{25}$ For Aetius' use of $\delta$ du see Syntagmation 37- of. Eunomius Apology 17:2. For Athanasius use of the same text see Oratio contra Arianos 3:6; De Synodis 35; and Ad Afros 4.

${ }^{26}$ De Decretis 22:3.

${ }^{27} \mathrm{Cf}$. the Neo-Arian statements quoted in the homoeousian memorandum at Epiphanius Panarion 73:21. There the name 'Father' is said to be revelatory of kfovola (power). It is clear from Eunomius Apology 17:5 that in later NeoArian terminology the term 'Father' denoted a Eutpreıa of God.

${ }^{28}$ De Decretis 29:4 and 30:4.
} 
never have had a large following, but public doctrinal debate was his forté. Basil was only the first in a long line of 'orthodox' opponents to write against Eunomius. ${ }^{29}$ His may not have been the most theologically acute refutation of Eunomius, but it was timely. It was written in the white heat of doctrinal controversy when few could have foreseen the collapse of the Neo-Arian movement after Eunomius' death in the 390's.

\section{(b) The knowledge of God}

It is characteristic of Eunomius' system that not only does he present the standard Arian picture of a carefully graded, hierarchical Trinity, but he seeks to undergird it with a distinctive theory of our knowledge of God. In his Apology he explains that there are two ways to the knowledge of God-one a deductive process from the essences (of the Unbegotten and the OnlyBegotten), the other an inductive procedure from the works or activities caused by these essences. It is worth quoting Eunomius' own words: 'There are two roads marked out to us for the discovery of what we seek: one is that by which we examine the actual essences and with clear and unadulterated reasoning about them make a judgement on each, the other is an enquiry by means of the actions, whereby we distinguish the essence on the basis of its products and completed works' ${ }^{30}$ Eunomius was confident that both of these roads would eventually demonstrate the dissimilarity in essence between the Unbegotten and the Only-Begotten. But it does not follow that the two roads are alternatives of equal weight. Decided priority is given to the deductive approach. ${ }^{31}$

Moreover, the second road turns out to be only a corollary of the first because Eunomius adds the presupposition that the creator of anything must always be superior to his creation. ${ }^{32}$ If the Son is the creation of the Unbegotten, as Eunomius argues, and the rest of the created order is the creation of the Son, the undisputed superiority of the Son over

\footnotetext{
${ }^{29} \mathrm{Cf}$. Vaggione op. cit. xiii.

${ }^{30}$ Eunomius Apology 20:5-9. The translation is that of Vaggione op. cit. as are the other translations from Eunomius in this paper.

${ }^{31}$ See Vaggione op. cit. 11-2 for further details.

${ }^{32}$ Apology 20:14-5
} 
the created order is further proof of the superiority in essence of the Unbegotten over the Only-Begotten. ${ }^{33}$

Here was a new approach to the knowledge of God. Earlier Christian tradition had with virtual unanimity declared direct knowledge of God to be an impossibility ${ }^{34}$ I have already indicated that Arius held to this in an extreme form. How, then, was God to be known? The answer was through his works. Origen, for example, wrote, 'Our mind cannot behold God as he is in himself, therefore it forms its conception of the Creator of the Universe from the beauty of his works and the loveliness of his creatures' ${ }^{35}$ Or take this profound passage from Justin Martyr: "The Father of all has no name given him, since he is unbegotten. For a being who has a name imposed on him has an elder to give him that name. 'Father', and 'God', 'Creator', 'Lord', 'Master' are not names but appellations derived from his benefits and works. His Son... is called Christ because he was anointed and God ordered all things through him. The name Christ also contains an unknown significance, just as the title 'God' is not a name, but represents the idea, innate in human nature, of an inexpressible reality'. ${ }^{36}$

We have by contrast Eunomius' remarkable confidence that he could accurately describe God's essence. At the beginning of the dogmatic section of the Apology he writes: 'We have made our confession that God is one, and that he was brought into being neither by his own action nor by that of any other. For each of these is equally impossible. In fact, just as the maker must be in existence before the thing he brings into being, and the thing made must be later than its maker, by the same token a thing cannot exist before or after itself, nor anything else at all before God. If it did, it would surely be the first which had the dignity of Godhead rather than the second; for, after all, anything which can be said to come into existence by the action of another...has itself to be placed among created beings, and must properly be ranked among

\footnotetext{
${ }^{33}$ Cf. ibid. 26:10-2.

${ }^{34}$ Cf. Boniface Ramsey, Beginning to Read the Fathers (London, Darton, Longman and Todd, 1986) 44-7.

${ }^{35}$ De Principiis 1:1:6.

36Justin Martyr Apology II:5. The translation is that of Henry Bettenson, The Early Christian Fathers (OUP, 1956) 63.
} 
things which have come into existence by the action of God. So then, if it has been demonstrated now that God neither existed before himself nor did anything else exist before him, but that he is before all things, then what follows from this is the Unbegotten, or rather, that he is unbegotten essence' ${ }^{37}$ The lynch-pin of this argument is an idea of causation-God is himself uncaused, but the cause of everything else which has come into being. Once this premiss is accepted (and interestingly Justin Martyr had implied something similar ${ }^{38}$ ), the con-clusion of God's Unbegottenness followed. Even Basil, Eunomius' opponent, would not have demurred. ${ }^{39}$ Eunomius, however, had gone further and talked of God as being 'unbegotten essence'. Justin, who had subscribed to the idea of one Unbegotten and to an idea of causation similar to that of Euno-mius, had emphatically denied that we could form from this an adequate definition of God's essence: 'There is no one who can give a name to the ineffable God, and if anyone dares to say that there is one, he suffers from an incurable madness' ${ }^{40}$

Madness and pride were also to be Basil's comment on Eunomius' implied assertion that he had attained a knowledge of God's essence. ${ }^{41}$ At no point in his Apology, however, does Eunomius in as many words claim to know God's essence. This was an inference made by Basil. Strangely enough, in view of past Christian tradition, it was an inference with which the Neo-Arians were happy. ${ }^{42}$ Indeed, they came to see this as a

\footnotetext{
${ }^{37}$ Apology 7:2-11.

${ }^{38}$ Cf. Justin Dial. 5.

${ }^{39}$ However, M.V. Anastos in his article "Basil's Katá Euvoulov, A Critical Analysis" 78-80 in Basil of Caesarea-Christian, Humanist, Ascetic ed. P.J. Fedwick (Toronto, Pontifical Institute of Mediaeval Studies, 1981) points out that Basil and Gregory of Nyssa misrepresented Eunomius' meaning in the

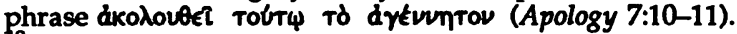

${ }^{40}$ Justin Apol. I:61. Justin, in turn, was dependent on Plato-cf. Kopecek op. cit. 253 n. 1.

${ }^{41}$ Adversus Eunomium 1:12. The standard edition of this work is that in the two-volume edition in the Sources Chrétiennes series edited by Bernard Sesboüe (Paris 1982).

${ }^{42}$ There is some evidence that originally the Neo-Arians held to Arius' doctrine of the Father's incomprehensibility even to the Son. This derives from the concluding section of their creed recorded at 4:6 of the Historia Acephalaedited by Annik Martin and Micheline Albert (1985). The authenticity of this creed has sometimes been doubted, mainly because its teaching does not altogether tie in with developed Neo-Arian theology. These doubts may be
} 
particularly useful weapon in public debate. ${ }^{43}$ The claim to a precise knowledge of God's essence would, after all, sound much more impressive to some ears than to say, as their opponents did, that true knowledge of God consisted in the recognition of his incomprehensibility. The Neo-Arian position also claimed a scriptural basis, particularly John 17:3.44

Neo-Arian claims, then, to a knowledge of God's essence emerged as a significant by-product of Eunomius' insistence on analysis of the term d $\gamma \in v \nu \eta T$ T. How was such a farreaching conclusion possible? We might point with G.C. Stead to a logical error. The Neo-Arians, he says, 'seem to have assumed that a definition sufficient to identify $x$ actually corresponds with and expresses all that $x$ is; consequently God's ovol $\alpha$, in the sense of his objective reality and character, is reduced to suit his oivl $\alpha$ in the sense of 'accepted identifying definition".45 This description of the logical processes behind the Neo-Arian position, however accurate, does not do justice to the mystique the Neo-Arians attached to the word

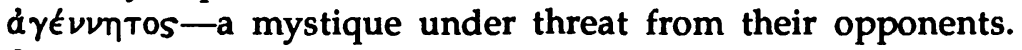
Some opponents held that it was merely a privative term, while others argued that the term was one of human invention $\left(\epsilon^{\prime} \pi\left(v \circ\llcorner a)\right.\right.$ and therefore suspect. ${ }^{46}$ Eunomius was particularly sensitive to the latter charge.

dissolved if we accept a substantial change in Neo-Arian thought on divine comprehensibility. Epiphanius (Panarion 76:4:1-2) confirms that the comprehensibility of the divine essence was a later development in the NeoArian position.

${ }^{43} \mathrm{Cr}$. Basil Epistle 234.

${ }^{44}$ For this text in the whole of the Arian controversy see the useful summary by Hanson op. cit. 836-7. This text is virtually the starting-point to The Confession of Eunomius (see esp. 2:1). In his index to the works of Eunomius Vaggione collects 8 allusions to this text.

${ }^{45}$ G.C. Stead Divine Substance (Oxford, OUP 1977$) 165$.

${ }^{46}$ Apology 8 cf. Aetius Syntagmation 12 (against $\left.\xi \pi l v o l a\right)$ and 19-20 (against privation). The noun $k \pi$ lvola and the related verb $k \eta\llcorner v \xi \omega$ sometimes carried associations of perverse, heretical invention-cf. C.R.B. Shapland The Letters of St Athanasius concerning the Holy Spirit (London, SPCK 1951) 76 n. 7:2. In this debate $\varepsilon \pi$ lvola is difficult to translate. Conception (Stead) or exercise of thought (Anastos) may be the most accurate English renderings. 


\section{(c) A theory of names}

To Eunomius it was impossible for merely human words to honour God. If the main feature of piety was to acknowledge that God is what he is, then human words will not do that; since, on Eunomius' view, words of man's invention dissolve as soon as they are uttered. ${ }^{47}$ This would seem a bold claim. Men do coin new words all the time, and often these words enrich our understanding of reality. Nor would we dismiss out of hand new theological terminology, though such language would

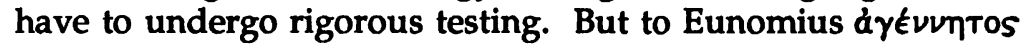
was God-given. Its incomparable connotations of perfection were explicable only on that basis. To undergird his contentions, Eunomius developed a whole theory of language, not confined simply to theological terminology. It is a mark of the significance he attached to this theory that Eunomius devoted one whole book (out of five) in his Apologia Apologiae to the question of language. ${ }^{48}$

This theory was based on Genesis 1, where Eunomius pointed out that God gave the names to various features of the created order-e.g. light, darkness and firmament-before man's creation. ${ }^{49}$ And so when man appeared on the scene, God had to give him knowledge of the appropriate names. According to Eunomius, Moses himself bears witness that the use both of the things named and of the names were given to men by the Creator as a natural capacity, and that the naming of the things is earlier than the generation of those who use them' ${ }^{50}$ If man had been left to work out for himself suitable names, he would have remained in irrationality and speechlessness. ${ }^{51}$ To deny, as Basil did, that the correct use of language was God's gift was to slight God's providence. ${ }^{52}$ Eunomius

47Apology 8:1-8.

${ }^{48}$ The Apologia Apologiae was Eunomius' belated response to Basil's attack on him in the Adversus Eunomium. Vaggione argues that this consisted of 5 books (op. cit. 79-81), of which we have fragments only from the first three. For details of the contents of these 3 books see ibid. 94-5.

${ }^{49} \mathrm{~W}$. Jaeger i:284.30 - 285.3. All references to this work derive from the second edition of Jaeger's Contra Eunomium in the collection Gregorii Nysseni Opera (Leiden, E.J. Brill 1960).

${ }^{50}$ Ibid. i:303.1-6.

${ }^{51}$ Ibid. i:342.21-9.

${ }^{52}$ Ibid. i:311.24-8 and 346.4-11. 
also felt, though he may not have said so specifically, that it underestimated man's dependence on correct use of language for successful functioning in the world. This principle lay at the heart of piety, as the Neo-Arians saw it, but it extended into other spheres of life. ${ }^{53}$

Eunomius disclosed how he believed man was endowed with language. God had not given to Adam a direct revelation which he had then to pass on to his successor. Rather, God gave man an innate faculty to use the correct names. Eunomius wrote, "The guardian of all things deemed it right to implant by a law of creation words in our psyches' ${ }^{54}$ Man's responsibility, then, was to direct that innate sense along the correct lines. Clearly Eunomius could not have considered that this sense worked automatically. Otherwise everyone would have agreed with him and his writings would have been superfluous!

Eunomius' theory had several difficulties to overcome, the most urgent being that of homonyms. ${ }^{55}$ For it was a common argument among Nicene exponents to suggest that if in Scripture the same titles - e.g. 'Light', 'Life', 'Power'-were applied to the Son as to the Father, they must be the same in essence. ${ }^{56} \mathrm{~A}$ similar line of argument was later to help establish the deity of the Holy Spirit. 57 It was vital that Eunomius meet this argument because he had set forth the principle that names imply essences. Eunomius modified this principle by an appeal to the transcendent natural reality of things-The natures of objects are not naturally consequent on the verbal expressions; rather, the force of words is accommodated to the objects in accordance with their proper status' ${ }^{58}$ In other words, the Neo-Arian theory of names did not stand by itself; it was a support for the keystone of the system-an hierarchical notion of reality. Eunomius had inserted a clear statement about this near the beginning of his Apologia Apologiae. "There is the

\footnotetext{
${ }^{53}$ Cf. T.A. Kopecek "Neo-Arian Religion: The Evidence of the Apostolic Constitutions" 172-5 in Arianism-Historical and Theological Reassessments ed. R.C. Gregg (Cambridge, Mass, Philadelphia Patristic Foundation 1985).

54 Jaeger op. cit. i:386. 18-20.

${ }^{55}$ Eunomius addresses this problem in Apology 19.

${ }^{56}$ E.g. Athanasius De Synodis 49.

${ }^{57}$ E.g. Basil De Spiritu Sancto 48; Gregory Naz. Oratio 31:29.

${ }^{58}$ Apology 18:7-9.
} 
supreme and absolute essence, and there is the essence which exists because of this one but after it, though before all others, and there is a third essence, which is ranked in no way with these, but is ranked below the first as its cause and below the second as the activity according to which it has been generated. There must also be included in this summary of the whole account the activities which follow the essences and the names which naturally belong to them. Now, each essence both exists and is conceived as absolutely simple and completely one in relation to its own dignity'.59

These views of natural rank and dignity were used by Eunomius to clarify the force of homonyms. This approach worked reasonably with the term 'eye'. Though used of God and of men in the Bible, clearly it could not denote the same thing in both cases. But Eunomius went further. If terms like 'Light', 'Life' and 'Power' were used of the Son as well as of the Supreme Being, that did not mean a sharing of or a likeness in essence. These terms could be understood only from the

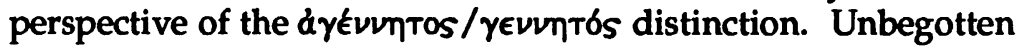
light was as vastly different from begotten light as unbegottenness was from begottenness. The only alternative was to make light a quality alongside unbegottenness in God's essence, and then to make this quality a common feature between God and the Son. But this would infringe the simplicity of God's essence. As a corollary, Eunomius asserted that all words signifying the essence of the Father were synonymous with the Unbegotten. Similarly, because the Son was also simple, all epithets applying to his ov่ola were equivalent to offspring ( $\gamma \in v \nu \eta \mu \alpha){ }^{60}$

Such stress on the divine simplicity left Eunomius in a strange position. On the one hand he was arguing that correct linguistic usage was a God-given key into the nature of reality. At the same time he was implying that God had effectively given men a number of different terms to reveal his reality. Some of these were scriptural, like $\omega \nu$ (I am) and $\mu \delta \nu \circ s$

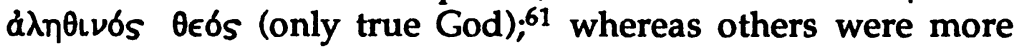

${ }^{59}$ Jaeger op. cit. i:71.28ff.

60 Ibid. 19:8ff.

${ }^{61}$ Ibid. 17:2-3. 


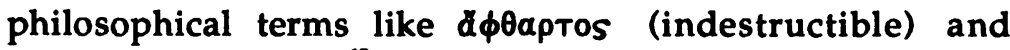
daduatos (deathless). ${ }^{62}$ All of these, Eunomius insisted, meant the same as a $\gamma \in v \nu \eta T o s .63$ He made no distinction between sense and reference. Eunomius' view then, as now, seemed to run counter to the commonsense application of these words. It also raised a question mark about God's wisdom-why should he have given us different words for the same reality?

Incidentally, Eunomius' theory about names and essences does explain a statement which outraged many-'God does not know anything more about his essence than we do, nor is that essence better known to him and less to us; rather, whatever we ourselves know about it is exactly what he knows, and, conversely, that which he knows is what you will find without change in us' ${ }^{64}$ No doubt, Eunomius presented this belief in a deliberately provocative way. But the statement does tie in with Eunomius' theory of divine revelation as deriving not simply from scripture but from a divinely implanted knowledge of names. If God had revealed his own name to men-and Eunomius' interpretation of Exodus 3:14 suggests he believed God had done so-then it was a mark of sheer unbelief to fail to explore the knowledge implied in that name.

Eunomius is often criticized as a rationalist. ${ }^{65}$ This judgement is too bland. In the sense that his concept of piety lacked a mystical element, he may be so called. But he was no rationalist in the modern sense of someone who considers revelation inferior or irrelevant to the use of reason. Only, revelation for Eunomius was Scripture plus the divinely implanted knowledge of names. Eunomius had introduced a second authority alongside and equal to Scripture. Therefore, contemporary criticisms that a $\gamma \in \nu \nu \eta \eta T$ (and some might want to add $d \pi \lambda \circ v_{s}$ ) were unscriptural carry some weight. But Eunomius with his interpretation of Genesis 1 would not have envisaged any conflict between his twin authorities-Scripture and language.

\footnotetext{
62 dф0артоs-Ibid. 28.9-10 doduatos at Jaeger op. cit. i:401.8 and 27.

${ }^{63}$ Jaeger op. cit. i:370.20-3.

${ }^{64}$ Fragment ii in Vaggione's edition (178-9). Vaggione gives a convincing defence of its authenticity at 167-70.

${ }^{65}$ The most recent such assessment is that of Hanson op. cit. 632 who talks of Eunomius' 'all-prevailing rationalism'.
} 
Indeed, he would probably not have recognised that he was working with two authorities at all!66

\section{The Cappadocian response}

\section{(a) $E \pi$ lvola as a way to knowledge.}

Basil's starting-point was Eunomius' assertion that words spoken by way of $\xi \pi$ lvola dissolved into thin air as soon as they were uttered. Basil regarded this as absurd since even the fanciful creations of the poets (like centaurs) remain lodged in the mind after the words have been spoken. ${ }^{67}$ But this was only one rather limited use of $z \pi(v o\llcorner a$, to which Basil was keen to attribute a more positive role. He pointed out that many objects seem simple or straightforward at first sight, but on closer examination prove more complex. Reflection on a simple body, for example, breaks it down into its constituent parts-its colour, form, hardness, size etc. Again, the idea of corn is a straightforward one recognised by everyone at first sight; but further reflection will lead to the different concepts of fruit, seed and nourishment. ${ }^{68}$ This was a type of $\xi \pi l \nu o\llcorner a$ which was far from useless. In effect, Basil was consciously employing a much wider sense of $k \pi$ lvola than that entertained by Eunomius. For Basil $\xi \pi(v o l a$ was that function whereby our minds process the raw material of sense data. It differed little from $\theta \in \omega \rho / \alpha$ (reflection). ${ }^{69}$ Scholars have regarded such an epistemological approach as Epicurean. ${ }^{70}$ It is, therefore, little wonder that Eunomius did not hesitate to accuse Basil of denying divine providence. This, however, did not touch the heart of the issue, which was not whether God conferred knowledge on men, but how. Eunomius had ascribed a passive role to men, whereas Basil's theory of $\epsilon^{\prime}$ lvola left man with a much more active responsibility in his bid to understand the world.

\footnotetext{
${ }^{66}$ It is clear from Apology 17:12-3 that Eunomius in his own way believed in the inerrancy of scripture.

${ }^{67}$ Adversus Eunomium 1:6:6-18.

${ }^{68}$ Ibid. 1:6:21ff.

${ }^{69}$ Cf. ibid. 1:6:56.

${ }^{70} \mathrm{Cf}$. Kopecek op. cit. 376. Eunomius also detected Epicurean echoes in Basil's work-cf. Jaeger op. cit. i:345.25-29.
} 
Basil claimed that scripture supported his principle of $z \pi$ (vola. Following a tradition which went back at least as far as Origen, he pointed to certain titles applied to Christ by way of ' $z$ lvola-e.g. 'Door', 'Bread', 'Vine', 'Light'. ${ }^{71}$ These names required reflection because Christ was not someone with several names, nor were the names synonymous. ${ }^{72}$ These different titles had been used to express the range of Christ's activities and the varied ways in which Christ brought benefit to man. He might, for example, be described as 'The Light of the World' not only to signify the inaccessibility of the glory inherent in his deity, but to indicate that by his own exceptional knowledge he illuminates those who have had their souls purified. ${ }^{73}$ To Basil that Scripture itself should employ the technique of $\xi \pi$ (vola was refutation enough of Eunomius' dismissive treatment.

Gregory of Nyssa took a high view of $\xi \pi l \nu o l a$, maintaining that all human skills depended upon it, whether these be theoretical (like logic and geometry) or practical (like agriculture and navigation). ${ }^{74}$ He backed up this claim with recourse to a definition which built on Basil's but went further. He suggested that $\xi \pi$ lvola was 'the method by which we discover things that are unknown going on to further discoveries by means of what adjoins to and follows from our first perception with regard to the thing studied' ${ }^{75} \mathrm{He}$ claimed justification for the place of $\xi \pi$ lvola in human technology by referring to the Septuagint version of Job 38:36, which declares that God has set men over the arts, while he has given to woman her skill in weaving and embroidery. ${ }^{76}$ It was to Gregory's mind absurd to suggest that God actually superintended the work of every single weaver or artisan by his immediate presence. Rather, God had given to men and women the initial intelligence whereby they might in time develop the specific sciences and disciplines. This perspective could be applied to language. God was responsible both for the realities of the world in

\footnotetext{
${ }^{71}$ Adversus Eunomium 1:7.4ff. cf. Stead op. cit. 142 for Origen's contribution.

${ }^{72}$ Adversus Eunomium 1:7.9-10.

73 Ibid. 1:7.17-21.

${ }^{74} \mathrm{Jaeger}$ op. cit. i:277.7f.

${ }^{75}$ Ibid. i:277.20f.

${ }^{76}$ Ibid. i:278.4f.
} 
which we live and for the rational faculty in man which makes coherent speech possible. ${ }^{77}$ But it was then up to man to use that reason to devise words to suit his own purposes. Eunomius had been guilty of ignoring this human element in language construction and the very diversity of human languages.

Gregory's view of $z$ mlvola, therefore, was not tied to a theory of perception via sense data. It was more closely (and we might say more appropriately) linked to God's providential dealings. In a debate where it is Eunomius who is often considered the rationalist par excellence, a high view of human reasoning is implicit in Gregory's account. By contrast, Eunomius counts the employment of human reason to devise terms for God as at best doomed to failure, or at worst blasphemous.

Basil had developed his theory of $\xi \pi$ (vola partly to

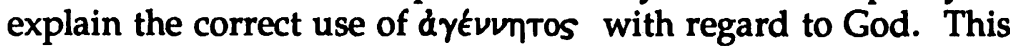
term, he contended, relates to our perception of time. When we look to past ages and find that God's life transcends all begin-

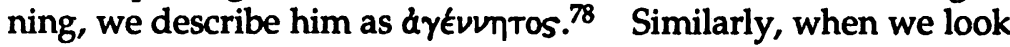
to future ages and see God as bound by no end or limit, we correctly describe him as $₫ \phi \theta \alpha p$ Tos. It may seem rather strange to link our perception of time to a general theory of sense perception, and it is no surprise to find Gregory of Nyssa quietly dropping all reference to time. Instead, he proposed to link a $\gamma E v \nu \eta T$ Tos to a question men are bound to ask-does the First Cause (i.e. God) exist without beginning or is his existence dependent on some beginning? Gregory proceeded, 'Perceiving, by the aid of thought, that that cannot be a first Cause which we conceive of as the consequence of another, we devised a word expressive of such a notion, and we say that He who is without anterior cause exists without origin or, so to say, ungenerately' ${ }^{79}$ Both Basil and Gregory, then, have their logical explanations as to how dyevuntos comes to be applied to God.

\footnotetext{
77Ibid. i:295.13f.

${ }^{78}$ Adversus Eunomium 1:7.37-44.

${ }^{79}$ Jaeger op. cit. i:280.22f. The translation is that of M. Day in the Nicene and

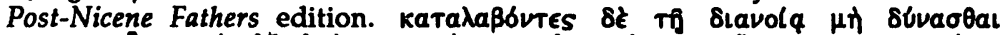

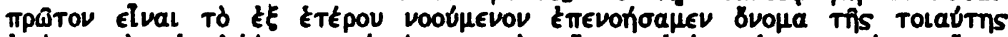

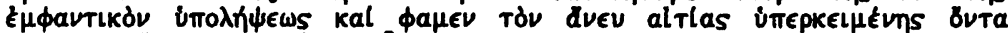
duápXws etTow dyeuntitus elvai.
} 
Nor is this their only contribution. Starting from the position that no one term can give an accurate picture of God's nature, Basil and Gregory divided words about God into two categories-those expressive of some quality God does possess and those indicative of some quality he does not. Our knowledge of God-such as it is-is an amalgam of both sorts of words. ${ }^{80}$ 'A $y \in v \nu \eta T$ Tos was one word which denotes what God did not possess; it indicates that God was not born. ${ }^{81}$ In that case it cannot disclose God's essence. Thus the Cappadocians argued against

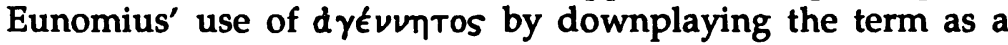
legitimate, but essentially privative expression.

\section{(b) A positive view of knowledge}

The Cappadocians' view of dytuvmtos formed part of their wider view of the knowledge of God. They rejected Eunomius' claim to have grasped the essence of God. Such a claim was contradicted both by scripture and by common notions (or general revelation), which might agree there was a God, but not on the sort of being this God was. ${ }^{82}$ Again, if it was impossible for men either from their own senses or from scripture to determine the essence of the earth, a mere sensible reality, how much less likely were they to grasp God's essence. ${ }^{83}$ A further corollary of Eunomius' position which proved unacceptable to the Cappadocians was the denial to the Son and the Holy Spirit of that special knowledge of God assigned to them by the Scriptures. ${ }^{84}$ This special knowledge was freely termed by Basil a knowledge of God's essence.

Basil has disappointingly little to say on man's positive knowledge of God other than to repeat traditional statements about such knowledge being conveyed through God's works. ${ }^{85}$ Epistle 235 is typical-'In respect of faith in God, the notion of the existence of God precedes, and this notion we gather from his works. For it is by perceiving his wisdom and

\footnotetext{
${ }^{80}$ Basil Adoersus Eunomium 1:10.1-10; for Gregory see Jaeger op. cit. i:395.14f.

${ }^{81}$ Adversus Eunomium 1:10.36-7.

${ }^{82}$ Ibid. 1:12.7f.

${ }^{83}$ Ibid. 1:12.30f.

${ }^{84}$ Ibid. 1:14.1-16. Basil based his position on the passages Matt 11:27 (of the Son's knowledge) and 1 Cor 2:10-11 (of the Spirit's knowledge).

${ }^{85}$ Basil uses the words Evtpyetal (Epistle 234) and 8nuouprifata (Epistle 235).
} 
power and goodness and all his invisible qualities as shown in the creation of the universe, that we come to a recognition of him. Thus we also accept him as our Lord'. ${ }^{86}$ Here there is a clear reference to Romans 1:20. It is strange, however, that Basil should confine himself to a passage on general revelation. Significantly, when he deals with John 1:18 concerning the unique knowledge brought by the Son of God to man, he puts a tame alternative - did the Son bring knowledge of God's essence or of God's power? ${ }^{87}$ Basil believes it will be self-evident to all but a Neo-Arian that the answer is God's power. But Basil is himself unconsciously restricted by the contemporary distinction between 'essence' and 'power' (or 'activity'). Rejecting Neo-Arian theories of a knowledge of God's essence, he has to explain every other sort of knowledge of God as a knowledge mediated through his activities.

Gregory of Nyssa used a wider canvas than Basil for his teaching about our knowledge of God. He agreed with Basil's basic epistemological approach that any knowledge of God's essence was a will of the wisp, and so all true knowledge of God must derive from his activities. This could even be seen in the word $\theta \epsilon \delta s$ (God) which Gregory believed ultimately to derive from God's activity in seeing $(\theta \epsilon \hat{a} \sigma \theta a l)$ all things. ${ }^{88}$ Since God's activities were varied, so were the descriptions given of them. The various different epithets applied to God were no more synonyms in his case than they were with men. ${ }^{89}$ Nor did any denote the divine essence. It was part of God's glory that he was 'above every name'.90

Two presuppositions undergirded Gregory's presentation. The first was his insistence on God's infinity. If the infinite God lay beyond the power of man to grasp, it was useless for God to talk to man in ethereal language commensurate with his own dignity. God had to condescend to use human speech.91

\footnotetext{
${ }^{86}$ The translation is that of R.J. Deferrari in the Loeb edition (vol. 3 379).

${ }^{87}$ Basil Epistle 234.

${ }^{88}$ Jaeger op. cit. i:397.8f.

${ }^{89}$ Ibid. i:315.24f.

${ }^{90} \mathrm{Ibid}$. i:397.26-8. Gregory was fond of using Philippians 2:9 to support his position.

${ }^{91}$ Here Gregory was drawing on a theme already developed by Origen-see R.P.C. Hanson Allegory and Event (London 1959) $225 \mathrm{f}$.
} 
His action on the Day of Pentecost in enabling different groups of people to hear the gospel in their own language was one example of a procedure God had employed repeatedly in human history. 92 God used ordinary human speech, and when he wanted to convey knowledge about himself, he used analogies from human characteristics. Gregory thus had his own way of tying language to God's providential dealings, but he left language as a distinctly human phenomenon. Gregory had taken great pains-perhaps too great pains-to demythologise Eunomius' view of language.

Gregory's other main presupposition was a distinction between sensible and intelligible reality. Whereas knowledge of sensible reality was open to all and clearcut, knowledge of intelligible reality was much more difficult to grasp. ${ }^{93}$ Knowledge of our own souls as well as knowledge of God fell into the latter category. ${ }^{94}$ Clearly Gregory did not accept sense perception as a complete explanation of our grasp of reality. It certainly had its part to play, notably in the initial stages of assimilating knowledge of God's works; but it was hardly the whole story. Gregory's approach, therefore, was more nuanced than that of Basil.

\section{(c) The Cappadocians and divine simplicity}

Eunomius had sought to back up his emphasis on unbegottenness by appealing to divine simplicity-a concept universally recognised among Christians of that time, but perhaps for that very reason not thoroughly investigated. Eunomius simply assumed God's simplicity. Implicitly he gave a sort of definition when he wrote of the Unbegotten that he does not exist within the Supreme Being 'as something separate (for he is simple and uncompounded)'.$^{95}$ In other words, to affirm God's simplicity was near to denying that God was compounded of different elements. Certainly, Basil and Gregory of Nyssa assumed this, and effectively included $\& \pi \lambda$ ovos among those

\footnotetext{
92 Jaeger op. cit. i:296.5f.

${ }^{93}$ Ibid. i:393.17f.

${ }^{94}$ Ibid. i:257.26f.

${ }^{95}$ Apology 8:16 of. 28:3-4.
} 
terms which spoke of those qualities God did not possess. ${ }^{96}$ I would surmise that Eunomius would have preferred a much more positive definition.

With Eunomius the term 'simple' was not confined to his Supreme Being. The Son and the Spirit, were also simple. ${ }^{97}$ Up to a point Basil was happy with this and built it into an argument that if the Father and the Son shared this quality of simplicity, they must be like in essence. ${ }^{98}$ Basil could do this because he saw the divine simplicity pertaining to the divine essence, which was carefully to be distinguished from the individuating characteristics of the Father and the Son. Effectively, Basil viewed the Father as simple not so much because he was Father as because he was God. And similarly with the Son.

In affirming the simplicity of his three Supreme Beings, Eunomius made a rigid differentiation between them. There was no partitioning or outflowing of the essence of the Supreme Being towards the Son. The Son's being was determined solely by the will of God. As Eunomius himself put it, He did not, however, share out anything of his own substance with the one begotten (for God is immortal, undivided and indivisible, and what is immortal cannot share out its own essence), nor did he establish any other like himself (for only he is unbegotten, and nothing can be begotten which is like the unbegotten essence), nor, indeed, did he make use of his own essence in begetting, but of his will only, nor beget anything like his own essence, but rather, what he willed, such he begot'.99 In other words, Eunomius was in metaphysical terms a supreme voluntarist. Or we might say that Eunomius' God engaged in activities-activities of his will-rather than possessed qualities. ${ }^{100}$ Indeed, Eunomius used the simplicity of God's essence as one ground carefully to distinguish activity from essence. ${ }^{101}$ In conclusion, Eunomius stated,

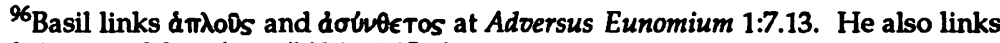

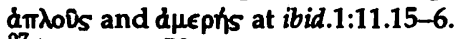

${ }^{97}$ As at note 59 supra.

${ }^{98}$ Adoersus Eunomium 1:23.11-15.

${ }^{99}$ Apology 28:8f.

${ }^{100} \mathrm{Cf}$. Kopecek op. cit. 468.

${ }^{101}$ Apology 23:4f.
} 
We must believe that the action which is the truest and most befitting God is his will, and that that will is sufficient to bring into existence and to redeem all things, as indeed the prophetic voice bears witness: 'Whatever he willed to do, he did'. ${ }^{102}$

Eunomius was not bound to say that all names used in any respect of God were synonymous. For he drew a big distinction between God's essence and his activities. Some names-like 'Father' and 'Maker' and doubtless others-could be applied to God by virtue of his activities. ${ }^{103}$ These names varied in meaning from one another just as the different activities varied. But the knowledge such names conveyed of God would be inferior to that deriving from the unchanging essence of God. And since that unchanging essence was simple, all words used of it amounted to 'unbegotten'.

Basil was also happy to distinguish God's essence and his activities. He argued that the former was incomprehensible, while the latter were the appropriate route to knowledge of God. For Basil, then, the distinction between God's essence and his activities involved that of comprehensibility. It was no problem to Basil that many names should be ascribed to God, since God's activities are varied, and we derive our knowledge of God from an amalgam of these activities. God's essence, however, remained beyond our horizons. 'For his activities descend to us, but his substance remains inaccessible' ${ }^{104}$ There could be no one correct starting-point for our knowledge of God; several were possible. At best our knowledge of God is partial, and Basil liked to quote 1 Corinthians 13:9 to substantiate this point. ${ }^{105}$

Basil had also to tackle the nature of God's simplicity in his analysis of Father/Son and Unbegotten/Only-Begotten language as applied to God. Basil's first foray into this territory occurred in his response to Eunomius' treatment of the words 'Light', 'Life' and 'Good' applied to both the Father and to the Son in the Scriptures. You may recall that for Eunomius these words did not have the same connotation as applied to the Father and to the Son; their sense was dictated by the

102 Ibid. 23:16f.

${ }^{103}$ Jaeger op. cit. i:371.5-9.

${ }^{104}$ Basil Epistle 234 (Deferrari Vol.3 373).

${ }^{105}$ E.g. Epistle 235 (380-2). 
primary distinction between the Unbegotten and the Begotten. But for Basil it was a foolish philosophical error to include both unbegottenness and begottenness within the category of substance. ${ }^{106}$ Even pagan philosophers had recognised the impossibility of having contradiction within substance. The way out of this impasse was to see the unbegotten and the begotten as 'certain distinctive properties observed in the substance' ${ }^{107}$ Hence the difference between them in no way affected the unity of their nature or their common substance; they simply allowed distinctions to be made within that common substance. The Godhead would be common, while fatherhood and sonship were individual properties. It was by putting the two together-both the common and the particular-that we can gain an appropriate knowledge of the truth. ${ }^{108}$

In his handling of the words Father/Son and Unbegotten/Only-Begotten Basil had effectively forged a new distinction for language about God. Some words marked out distinctions within the common divine nature, while others simply referred in some way to that nature. Words in the former category could not infringe the divine simplicity, seeing that they were not being used to describe part of the divine essence. ${ }^{109}$ Here Basil was not so much offering a rigorous analysis of the divine simplicity as providing a framework to circumvent some of its more serious difficulties. Of course, as Basil was well aware, he was simply employing the general/particular distinction familiar from other spheres to that of God. He cited the example of animals where such distinctions as that between the winged and the pedestrian in no way derogate from the one underlying animal substance. ${ }^{110}$ It is unclear how far Basil wished to press the analogy with the Godhead. Was the Godhead a common genus with three individual members? Or was something more involved? We cannot say for certain. ${ }^{111}$ Basil was not concerned with detailed

\footnotetext{
${ }^{106}$ Adversus Eunomium 2:28.15f. Sesboüé thinks Basil has in mind Aristotle Categories 5,36, 22-7.

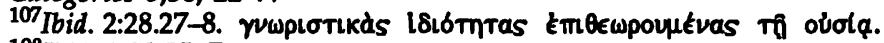

${ }^{108}$ Ibid. 2:28.35-7.

${ }^{109}$ Ibid. 2:29.

110 Ibid. 2:28.47-50.

${ }^{111}$ Cf. Hanson's discussion at op. cit. $696-9$ see (note 3).
} 
analysis of the divine simplicity in relation to the Trinity. He was content to take his cue from the Christian tradition of words like Father and Son (and to a lesser extent, Unbegotten and Begotten) and to marry this with the philosophical principle whereby contrariety was not allowed within substance.

Basil was happy to refer the words 'Light', 'Life' and 'Good' to God's substance as long as none of them was said solely to define that substance. Then, Basil thought, God's simplicity would be adequately safeguarded if God were affirmed to be wholly Light, wholly Life and wholly Good. ${ }^{112}$ But this is as far as he would go.

It is striking how self-evident the divine simplicity appeared to Gregory of Nyssa-We believe that the most boorish and simple-minded would not deny that the Divine Nature, blessed and transcendent as it is, is 'single'. That which is viewless, formless, and sizeless, cannot be conceived of as multiform and composite' ${ }^{113}$ One corollary of simplicity was that God does not possess goodness but is identical with goodness. Gregory's main concern, however, was to scout any notion of greater and lesser within the Divine Nature-which he found inconsistent with simplicity. This enabled him to accuse Eunomius of effectively destroying the divine simplicity either through his hierarchical concept of the Trinity or (perhaps more to the point) through the invocation of an inferior form of simplicity in the cases of the Son and the Holy Spirit. There is no place, he contended, for degrees of simplicity. But we do not find any treatment of how a Triune God is compatible with absolute divine simplicity. At one point Gregory did foreshadow the doctrine which became known as coinherence or circumincession-'All the attributes of the Father are beheld in the Son, and all the attributes of the Son belong to the Father, in so much as the Son abides wholly in the Father and in turn has the Father wholly in himself ${ }^{114}$ This might have helped to tie in his doctrine of the Trinity with the divine simplicity, but Gregory does not develop the point.

${ }^{112}$ Adversus Eunomium 2:29.17-21.

${ }_{113}$ Jaeger op. cit. i:94.17-22.

${ }^{114}$ Basil Epistle 38 (Deferrari Vol. 1 p.227). Though this letter is included in the manuscripts of Basil's letters, recent scholarship inclines to the view that Gregory of Nyssa was the author-see Hanson op. cit. 723 n. 174. 
In short, the Cappadocians suggested that various terms can be happily applied to God's essence, simple though that may be, because they are merely partial and human conceptions. Changes in our talk about God derive from changes in us and not from any compositeness in God himself. ${ }^{115}$ No doubt, the Cappadocians were strongly influenced by their epistemology as based on our sense perception. But there was another Christian tradition which at least as early as Irenaeus had promoted an alternative solution-that the divine attributes are identical both with each other and with their possessor. ${ }^{116}$ In the light of the ground chosen by Eunomius, for the Cappadocians to have espoused the latter position could have been construed as agreement that all the divine attributes were identical with unbegottenness. And that would simply have played into Eunomius' hand.

\section{Conclusions}

It is of perennial importance to determine how we may attain a true knowledge of God. Then we must ask how much that knowledge allows us to say about God.

Eunomius and the Cappadocians gave opposite and extreme answers. Eunomius claimed knowledge of God's very essence through rigorous analysis of the term dytuvntos. This, in turn, was built up on a striking theory of language. At first sight Eunomius' view holds some attraction. It is based on the narrative of Genesis 1-2, where God names various things before man appears on the scene, and God initiates conversation with Adam. But the theory tends to fizzle out when we realise it was promoted in the interests of justifying two inter-related words-'unbegotten' and 'begotten'. As Eunomius proceeds to make all words applying to God's essence synonymous with a $\gamma \in \nu \nu \eta T o s$ and all words applying to the Son's essence synonymous with $\gamma \in \varepsilon_{\nu} \eta \mu \alpha$, he has clearly departed from any straightforward view of language.

But even supposing we could modify Eunomius' thesis and say that God only taught men the most appropriate words

${ }^{115} \mathrm{Cf}$. Stead's analysis at op. cit. 163.

${ }^{116} \mathrm{Ibid}$. 163-4 and 187-9. 
about himself, 'unbegotten' faces the obvious objection that it is unscriptural. Besides, it is far from self-evident that words applied in Scripture to God are equivalent to 'unbegotten' or to one another. Eunomius' concept of the divine simplicity as identifiable with one ultimate term must be fallacious. Scripture, in effect, avoids giving God a name. Surely Justin was correct in his assertion that the very act of naming God would be an assumption of superiority over God.

And yet Basil, and to a lesser extent Gregory, go to an opposite pole. The language we use of God and of other things may indeed be a human construct. And for God to use that language may involve considerable condescension. Such would be undeniable. But it is a bold claim that all language has its origin in our sense experience and in our reflection thereon. I have already commented on the oddity of Basil including an analysis of time within our sense experience. The difficulty of his position becomes even more acute when we consider specifically theological issues. Could we understand the incarnation or the cross on the basis of sense experience alone? The place of specific verbal revelation was being overlooked.

The Cappadocians correctly stated that appropriate linguistic usage requires reflection. Words are not automatic keys into reality. (Eunomius himself implicitly admitted as much!) But if language does contain a human element, biblical Christians should be the last people to ignore its divine dimension. Interestingly, a modern writer on this theme, Carl Henry, regards the linking of the origins of language to the processing of sense data as typical of unbelieving evolutionary thinkers. ${ }^{117}$ The Cappadocians would have found themselves in strange company!

The significance of the Cappadocian position may become clear from a couple of errors into which they fell. First, amid discussion of titles like 'Vine', 'Door' and 'Shepherd' ascribed to Christ, Basil had virtually assumed that early Christians had given them to Christ by reflection on his activities towards them. ${ }^{118}$ Eunomius pounced on this as a clear

${ }^{117}$ C.F.H. Henry God, Reoelation and Authority (Waco, 1979) Vol. 3 386-7.

${ }^{118}$ Basil Adversus Eunomium 1:7.1-31. 
mistake. ${ }^{119}$ It was Christ who had applied these names to himself. Basil had missed the divine initiative behind this language.

Then, the Cappadocians felt little need to distinguish between general and special revelation. ${ }^{120}$ Here they were drawing from an apologetic tradition which argued from Romans 1:20 and Wisdom 13:5 that God made himself known to men through the created order. Biblical revelation was understood simply as an extension to this. Furthermore, neither the Cappadocians nor Eunomius suggested that there was something special about God-talk. It is remarkable that in their very different theories language about God was simply considered as part of a wider view of human language.

This led to an insufficiently critical view of the use of non-biblical language. True, the Cappadocians and Eunomius could both, when it suited them, accuse the other side of being unscriptural, but these charges have a hollow ring since both sides effectively recognized the merits of using some non-biblical language. ${ }^{121}$ My point is a different one. There was a general failure to distinguish between such non-biblical language as might be warranted by the data of Scripture itself-e.g. the Trinity-and non-biblical language which derived from some philosophical tradition. Insufficient reflection on the latter could lead to the adoption of language which was either unclear or misleading since it was not fitted into the tenor of Scripture. Of course, it would be ludicrous to claim there was no reflection on terms from philosophical theology when one of the Cappadocians' greatest achievements was to diminish the

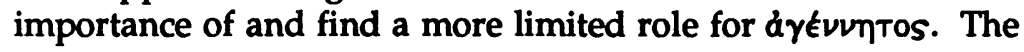

\footnotetext{
${ }^{119}$ Jaeger op. cit. i:313.16-18 and 315.31-316.3.

${ }^{120} \mathrm{Cf}$. the agglomeration of different divine titles and attributes (some biblical and some not) at Basil Epistle 234 (Deferrari Vol.3 p.372). Similarly Gregory of Nyssa at Jaeger op. cit. i: $396.27 f$ and Gregory of Nazianzus Oratio 28:7 and 9. This is not to deny that the Cappadocians had the concept of general revelation or 'common notions' (Kotvin Evvola). They did not explore its significance in any depth.

${ }^{121}$ Hanson op. cit. 848 argues that the pro-Nicene exponents in the fourth century established their position because they realised the need to have recourse to non-biblical language to explain biblical doctrines. By contrast, the Arians failed to make this step and suffered in consequence. This might apply to the Homoean Arians, but cannot be true of the Neo-Arians, who were perfectly happy to use non-biblical language.
} 
rudimentary reflection on God's simplicity, however, would be one example of the phenomenon I am alleging.

But a more serious legacy would be the acceptance of the distinction between essence (ovola) and activity ( $\dot{t} \nu \rho \gamma \in\llcorner a$ ) by both sides. Of course, they had different reasons. Eunomius wanted to establish the dissimilarity in essence between the Supreme Being and the Son, while the Cappadocians were determined to preserve the possibility of knowing something about God and yet leaving his essence incomprehensible. But the distinction is not one which derives naturally from any part of Scripture. Nor is it clearly preferable to the Aristotelian formula accepted by many medieval writers whereby God's substance or essence is defined as his energy..$^{122}$

This fourth-century distinction demanded at least a logical distinction between God's incomprehensible essence and even his uncreated and eternal energies. Such a distinction well fitted the Neo-Arian insistence that God relates to everything else solely through his will. Again, it accorded with the early Arian contention (which the Neo-Arians were to turn on its head) that God was incomprehensible to the Son and hence very remote to ordinary men. Though opposed to both these contentions, the Cappadocians betrayed a tendency unduly to limit the believer's knowledge of God. This is manifest in Basil's discussion of the knowledge of God which goes with true saving faith. This, he declared, is simply the knowledge that God is, not the knowledge as to what God is. Basil believed he was faithfully reflecting the meaning of Hebrews 11:6-' $\mathrm{He}$ that cometh to God must believe that God is...' (AV). ${ }^{123}$ But he took a minimising interpretation of the phrase 'must believe that God is' - the mere affirmation of God's existence.

Not surprisingly, Gregory of Nyssa, who in his Trinitarian works reaffirmed Basil's position, later developed

\footnotetext{
${ }^{122}$ Stead op. cit. 278-80. Even the term 'essence' by itself is far from clear-see ibid. p.157-66. For a modern controversy showing the same sort of confusion see J.M.Frame, The Doctrine of the Knowledge of God (Phillipsburg, NJ, Presbyterian and Reformed Publishing Co., 1987) 21-40.

${ }^{123}$ Quoted at Adversus Eunomium 1:14.42 and Epistle 234 (Deferrari 374).
} 
a different approach to the knowledge of God. ${ }^{124} \mathrm{He}$ advocated a sort of immediate and non-rational knowledge of God through the mystical ascent of the soul. Far from abandoning his earlier position, he was aware that in some sense the very incomprehensibility of God to the rational, but finite mind of man demanded another type of knowledge. Subsequent eastern theology, accepting Basil's scheme as against that of Eunomius, was liable to such developments, which it was always difficult to submit to scriptural controls. For Basil's framework left the church with rather a remote picture of God. Only his 'energies' come down to us, while all that is needed for salvation is belief in his reality. Eunomius, by contrast, had challenged earlier orthodoxy and claimed an exhaustive knowledge of God. In the process he gave the church such a fright that it was only too eager to take up those weapons which lay nearest to hand-the traditional assertion of divine incomprehensibility and the convenient philosophical distinction between essence (ovola) and activity $(\xi \nu \epsilon \rho \gamma \in\llcorner a)$. It is a pity that this ready-made answer precluded further investigation into what scripture means by the knowledge of God. It is a pity too that Eunomius' tendentious treatment of the divine origin of language-a promising idea in more competent hands-foreclosed for a time serious reflection on language as a vehicle of God's revelation.

${ }^{124}$ Hanson op. cit. p.721-2 gives a basic outline. Williams op .cit. 199-214 and 242-4 gives some very suggestive comments on the place of the knowledge of God within the whole of the Arian Controversy. 